\title{
PREVALENCE AND IMPACTS OF LOW BACK PAIN AMONG PEASANT FARMERS IN SOUTH-WEST NIGERIA
}

\author{
BOSEDE ABIDEMI TELLA, SUNDAY RUFUS AKINWUMI AKINBO, SAHEED ADELEYE ASAFA, \\ and CALEB ADEMOLA GBIRI
}

University of Lagos, Lagos, Nigeria

Department of Physiotherapy, College of Medicine

\begin{abstract}
Objectives: A relationship between low back pain (LBP) and poor postures has been previously established with a high prevalence observed in many occupations. This study aimed to investigate the prevalence of LBP, associated risk factors and impacts on farmers in South-West Nigeria. Materials and Methods: Six hundred and four farmers completed a 36-item closed-ended questionnaire which was translated to Yoruba language with content validity and back translation done afterwards. The questionnaire sought information on demographic data, 12-month prevalence, severity, history, causes and management of LBP, and its impacts on farm activities and the activities of daily living. Data was analyzed using the Statistical Package for Social Sciences (SPSS) version 17. Data was summarized using descriptive statistics of mean, range, frequency, standard deviation, percentage. $\mathrm{Chi}^{2}$ and Mann-Whitney-U test were used to find association between variables. The level of significance was set at $\alpha=0.05$. Results: The 12-month prevalence of LBP among the respondents was $74.4 \%$. Low back pain was described as moderate in $53.4 \%$. Prolonged bending $(51.3 \%)$ was the most related risk factor. A considerable proportion $(65.9 \%)$ of the respondents were unable to continue some of the previously enjoyed activities. Males had significantly higher $(\mathrm{p}<0.05)$ prevalence, recurrence and duration of LBP than the females. Conclusion: There is a high prevalence of LBP among farmers in South-West Nigeria. Age, sex and years of involvement in farming have a significant influence on the prevalence of LBP.
\end{abstract}

Key words:

LBP, Prevalence, Impacts, Peasant Farmers, South-West Nigeria

\section{INTRODUCTION}

Low back pain is the most common musculoskeletal problem and currently one of the most widespread musculoskeletal problems affecting human population [1,2]. It is considered as one of the most common health problems in the industrialized world, with estimates of $60 \%$ to $85 \%$ of the population experiencing it at some point during their lives [3]. Low back pain has been defined as pain limited to the region between the lower margins of the 12th rib and gluteal folds [4-8]. It has also been described as a condition in which patient feels an incapacitating pain at the lower part of the back [9].
Low back pain of mechanical origin is usually perpetuated and aggravated by poor posture and patients with low back pain generally report an increase in pain intensity with movement towards lumbar lordosis which is the normal curvature of the lumbar region [10]. Consequently, poor posture that reduces the lumbar lordosis usually places the ligamental structures of the back under stretch [11,12]. It is also believed that excessive periods spent in a poor posture may be contributory to the deterioration of the lower intervertebral discs with consequent pain in the low back [13].

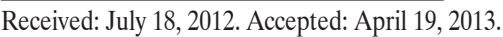

Corresponding author: B.A. Tella, Department of Physiotherapy, College of Medicine, University of Lagos, P.M.B 12003, Surulere, Lagos, Nigeria (e-mail: adedemi@yahoo.com). 
The four major musculoskeletal conditions leading to disability include osteoarthritis, rheumatoid arthritis, osteoporosis and low back pain [14]. The disability reported globally as a result of low back pain and loss of manpower, causing huge amounts of revenue loss has recently increased dramatically [15]. It has been estimated that over fifty billion dollars is spent annually on the diagnosis and treatment of back pain in the United States [16], while a hundred million dollars is spent annually in United Kingdom for the same purpose [17]. These figures are of great concern to physiotherapists and other healthcare professionals dealing with patients reporting low back pain. There is a global burden of disease of low back pain and suggestion that low back pain among Africans is rising and of concern [18]. Pain and loss of function associated with low back pain primarily leads to disability [14].

It has been established that there is a relationship between low back pain (LBP) and poor postures. It is one of the most commonly treated disorders in out-patient physiotherapy clinics worldwide [19] and has been found to have significant impact on functional ability, thereby restricting occupational activities with marked socio-economic repercussion [20]. Studies have shown high prevalence rates of LBP in office workers [21], hospital staff [8], nurses [6], bricklayers [22], standing workers, agricultural workers and carpenters [23], commercial and private automobile drivers [24], among commercial drivers and motorcyclists [25]. However, little is known about the prevalence of low back pain among farmers in the rural areas, particularly in Nigeria. This study therefore aimed to investigate the prevalence of low back pain, its associated risk factors and its impacts on farmers in Iwo, Osun State, South-West Nigeria.

\section{MATERIAL AND METHODS}

Six hundred and four farmers (368 males, 236 females) participated in the survey. They were recruited using a sample of convenience, from various farm settlements across the rural communities in Iwo Local Government Area of Osun State, South West Nigeria.

Participants were requested to complete a 36-item closedended questionnaire which consisted of five sections. The copies of questionnaire were self administered to the participants by one of the researchers and two trained assistants through personal visitations. The questionnaire collected information on demographic data, 12-month prevalence of LBP prior to the study, severity of LBP, history of LBP, causes and management of LBP and its effect on farm activities and activities of daily living. The questionnaire was translated to Yoruba language and content validity and back translation was done afterwards in the Department of Linguistics, African and Asian Studies, University of Lagos.

The study was approved by the Research Grant and Experimentation Ethics Committee of College of Medicine of the University of Lagos. Consent of the participants was also sought and obtained.

\section{Data analysis}

Data was analyzed using the Statistical Package for Social Sciences (SPSS) version 17. Data was summarized using descriptive statistics of mean, range, frequency, standard deviation, percentage. $\mathrm{Chi}^{2}$ and Mann-Whitney- $\mathrm{U}$ test were used to find association between variables. The level of significance was set at alpha level of 0.05 .

\section{RESULTS}

Four hundred and forty-seven (84\%) of the participants responded that they had experience of low back pain (LBP) during the last 12 months preceding the study, out of whom $78.4 \%$ were male and $21.6 \%$ were female (Table 1). Three hundred and twenty-three (53.5\%) participants reported gradual onset of their LBP while $20.5 \%$ had sudden onset (Table 1). Three hundred and twenty-two (53.3\%) had multiple episodes 
of LBP in the last 12 months, while $28.1 \%$ had experienced single episode (Table 1). Three hundred and twenty-eight (54.3\%) of the farmers with LBP described the nature of their pain as dull, while $19.9 \%$ said it was sharp (Table 1).

More (53.4\%) participants described their LBP as moderate while $23.1 \%$ described it as severe and required hospital visit. The most frequently reported LBP risk factor among the participants was prolonged bending (51.3\%), followed by long years of farming (28\%) (Figure 1$)$. There was a significant relationship between years of farming and age and 12-month prevalence of LBP (Tables 2 and 3). There was significantly higher 12 -month prevalence of LBP among males than females (Table 4). The point-prevalence of LBP among males was significantly higher compared to females (Table 4). There was significantly higher history of previous injuries among males than females (Table 4). Males had significantly higher $(\mathrm{p}<0.05)$ prevalence, recurrence and duration of LBP than the females. The majority $(54.1 \%)$ of participants had difficulty in doing farm work because of their LBP, while $103(17.1 \%)$ had their sleep disturbed. Higher number of the respondents (48.7\%) said they were prevented from participation in formerly practiced activities, such as sexual activities $(83,13.7 \%)$, attending parties $(54,8.9 \%)$, hunting $(26,4.3 \%)$, marketing $(48,8 \%)$ etc. they usually enjoyed (Table 5). Most (57.8\%) respondents had been absent from farm due to LBP (Table 5).
Table 1. Onset, nature, episodes and duration of low back pain (LBP) in respondents

\begin{tabular}{|c|c|c|}
\hline \multirow[t]{2}{*}{ Variables } & \multicolumn{2}{|c|}{$\begin{array}{l}\text { Respondents } \\
(\mathrm{N}=604)\end{array}$} \\
\hline & $\mathrm{n}$ & $\%$ \\
\hline \multicolumn{3}{|l|}{ Onset of LBP } \\
\hline gradual onset & 323 & 53.50 \\
\hline sudden onset & 124 & 20.50 \\
\hline no response & 157 & 26.00 \\
\hline total & 604 & 100.00 \\
\hline \multicolumn{3}{|l|}{ Episodes of LBP } \\
\hline single episode & 126 & 28.10 \\
\hline multiple episode & 322 & 53.30 \\
\hline no response & 156 & 25.80 \\
\hline total & 604 & 100.00 \\
\hline \multicolumn{3}{|l|}{ Nature of LBP } \\
\hline dull pain & 328 & 54.30 \\
\hline sharp pain & 120 & 19.90 \\
\hline no response & 156 & 25.80 \\
\hline total & 604 & 100.00 \\
\hline \multicolumn{3}{|l|}{ Duration of LBP } \\
\hline$<6$ weeks & 47 & 7.80 \\
\hline 6-12 weeks & 108 & 17.90 \\
\hline$>12$ weeks & 293 & 48.50 \\
\hline no response & 156 & 25.80 \\
\hline total & 604 & 100.00 \\
\hline
\end{tabular}

Table 2. Years of involvement in farming and 12-month prevalence of low back pain (LBP) in the respondents

\begin{tabular}{lcccccc}
\hline \multirow{2}{*}{$\begin{array}{c}\text { Involvement } \\
\text { (years) }\end{array}$} & \multicolumn{2}{c}{$\begin{array}{c}\text { Respondents with previous } \\
\text { history of LBP }\end{array}$} & \multicolumn{2}{c}{$\begin{array}{c}\text { Respondents with no previous } \\
\text { history of LBP }\end{array}$} & \multirow{2}{*}{ Chi $^{2}$} & p \\
\cline { 2 - 5 } & $\mathrm{n}$ & $\%$ & $\mathrm{n}$ & $\%$ & & \multirow{2}{*}{$0.00^{*}$} \\
$1-10$ & 6 & 20.00 & 24 & 80.00 & & \\
$11-20$ & 13 & 39.40 & 20 & 60.60 & & \\
$21-30$ & 43 & 58.90 & 30 & 41.10 & \\
$31-40$ & 115 & 74.20 & 40 & 25.80 & \\
$41-50$ & 141 & 81.00 & 34 & 19.00 & \\
\hline
\end{tabular}


Table 2. Years of involvement in farming and 12-month prevalence of low back pain (LBP) in the respondents - cont.

\begin{tabular}{ccccccc}
\hline \multirow{2}{*}{$\begin{array}{c}\text { Involvement } \\
\text { (years) }\end{array}$} & \multicolumn{2}{c}{$\begin{array}{c}\text { Respondents with previous } \\
\text { history of LBP }\end{array}$} & \multicolumn{2}{c}{$\begin{array}{c}\text { Respondents with no previous } \\
\text { history of LBP }\end{array}$} & Chi $^{2}$ & $\mathrm{p}$ \\
\cline { 2 - 4 } & $\mathrm{n}$ & $\%$ & $\mathrm{n}$ & $\%$ & \\
\hline $51-60$ & 95 & 92.20 & 8 & 7.80 \\
$61-70$ & 34 & 97.10 & 1 & 2.90 & \\
\hline
\end{tabular}

* Significant at $\mathrm{p}<0.05$.

Table 3. Association between age and 12-month prevalence of low back pain (LBP) in the respondents

\begin{tabular}{|c|c|c|c|c|c|c|}
\hline \multirow{2}{*}{$\begin{array}{c}\text { Age } \\
\text { (years) }\end{array}$} & \multicolumn{2}{|c|}{$\begin{array}{l}\text { Respondents with previous } \\
\text { history of LBP }\end{array}$} & \multicolumn{2}{|c|}{$\begin{array}{l}\text { Respondents with no previous } \\
\text { history of LBP }\end{array}$} & \multirow[t]{2}{*}{$\mathrm{Chi}^{2}$} & \multirow{2}{*}{$\mathrm{p}$} \\
\hline & $\mathrm{n}$ & $\%$ & $\mathrm{~N}$ & $\%$ & & \\
\hline$<25$ & 4 & 33.30 & 8 & 66.70 & 59.84 & $0.00^{*}$ \\
\hline $25-34$ & 28 & 40.00 & 42 & 60.00 & & \\
\hline $35-44$ & 96 & 70.10 & 40 & 29.40 & & \\
\hline $45-54$ & 141 & 80.10 & 35 & 19.90 & & \\
\hline 55-64 & 107 & 82.30 & 23 & 17.70 & & \\
\hline 65-74 & 54 & 90.00 & 6 & 10.00 & & \\
\hline$\geq 75$ & 20 & 100.00 & 0 & 0.00 & & \\
\hline
\end{tabular}

* Significant at $\mathrm{p}<0.05$.

Table 4. Gender influence on the history of low back pain (LBP) in the respondents

\begin{tabular}{|c|c|c|c|c|c|c|c|}
\hline \multirow[t]{2}{*}{ Variables } & \multicolumn{2}{|c|}{$\begin{array}{l}\text { Respondents } \\
(\mathrm{N}=604)\end{array}$} & \multirow[t]{2}{*}{ Mean rank } & \multirow[t]{2}{*}{ Sum of mean } & \multirow{2}{*}{$\begin{array}{c}\text { Mann- } \\
\text { Whitney-U }\end{array}$} & \multirow[t]{2}{*}{ Z-Score } & \multirow[t]{2}{*}{$\mathrm{p}$} \\
\hline & sex & $\mathrm{n}$ & & & & & \\
\hline \multirow[t]{2}{*}{ 12-month prevalence of LBP } & male & 272 & 287.93 & 105384.00 & 105384.00 & -2.941 & $0.003^{*}$ \\
\hline & female & 176 & 320.15 & 74916.00 & & & \\
\hline \multirow[t]{2}{*}{ Point-prevalence of LBP } & male & 272 & 287.80 & 105912.00 & 105912.00 & -3.620 & $<0.001^{*}$ \\
\hline & female & 176 & 324.23 & 76194.00 & & & \\
\hline \multirow[t]{2}{*}{ Recurrent LBP } & male & 270 & 230.74 & 66684.00 & 33892.00 & -1.462 & 0.144 \\
\hline & female & 174 & 213.16 & 33892.00 & & & \\
\hline \multirow[t]{2}{*}{ Previous back injury } & male & 272 & 307.01 & 109908.00 & 66213.00 & -2.878 & $0.004 *$ \\
\hline & female & 176 & 281.76 & 66213.00 & & & \\
\hline \multirow[t]{2}{*}{ Frequency of LBP } & male & 272 & 230.20 & 66527.50 & 34048.50 & -1.364 & 0.172 \\
\hline & female & 174 & 214.14 & 34048.50 & & & \\
\hline \multirow[t]{2}{*}{ Duration of LBP } & male & 270 & 221.00 & 63868.50 & 63868.50 & -0.919 & 0.358 \\
\hline & female & 176 & 230.00 & 36707.50 & & & \\
\hline
\end{tabular}

* Significant at $\mathrm{p}<0.05$ 
Table 5. Impacts of low back pain on respondents

\begin{tabular}{|c|c|c|}
\hline \multirow{2}{*}{ Variables } & \multicolumn{2}{|c|}{$\begin{array}{l}\text { Respondents } \\
(\mathrm{N}=604)\end{array}$} \\
\hline & $\mathrm{n}$ & $\%$ \\
\hline \multicolumn{3}{|l|}{ Stop work and rest } \\
\hline yes & 395 & 65.40 \\
\hline no & 51 & 8.40 \\
\hline no response & 158 & 26.20 \\
\hline \multicolumn{3}{|l|}{ Difficulty in doing farm work } \\
\hline yes & 327 & 54.10 \\
\hline no & 119 & 19.70 \\
\hline no response & 158 & 26.20 \\
\hline \multicolumn{3}{|l|}{ Disturbance of sleep } \\
\hline yes & 103 & 17.10 \\
\hline no & 343 & 56.50 \\
\hline no response & 158 & 26.20 \\
\hline \multicolumn{3}{|c|}{$\begin{array}{l}\text { Difficulty in practicing formerly } \\
\text { enjoyed activities }\end{array}$} \\
\hline yes & 294 & 48.70 \\
\hline no & 152 & 25.20 \\
\hline no response & 158 & 26.20 \\
\hline \multicolumn{3}{|l|}{ Reported activities } \\
\hline sexual activities & 83 & 13.70 \\
\hline attending parties & 54 & 8.90 \\
\hline friend visit and chatting & 50 & 8.30 \\
\hline hunting & 26 & 4.30 \\
\hline marketing & 48 & 8.00 \\
\hline snail picking & 7 & 1.20 \\
\hline tale telling & 26 & 4.30 \\
\hline no response & 310 & 51.30 \\
\hline \multicolumn{3}{|l|}{ Absent from farm } \\
\hline yes & 349 & 57.80 \\
\hline no & 97 & 16.10 \\
\hline no response & 158 & 26.20 \\
\hline \multicolumn{3}{|l|}{ Absence (days) } \\
\hline$<5$ & 74 & 12.30 \\
\hline $5-10$ & 145 & 24.00 \\
\hline$>10$ & 130 & 21.50 \\
\hline no response & 255 & 42.20 \\
\hline
\end{tabular}

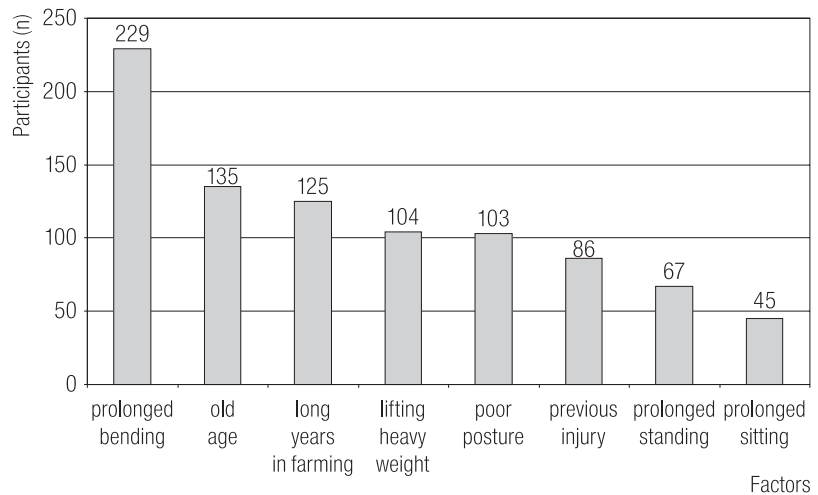

Fig. 1. Predisposing factors associated with low back pain in the respondents

\section{DISCUSSION}

The finding that the prevalence of low back pain among farmers in south West Nigeria is very high (74.4\%) shows that manual farming predisposes to occurrence of low back pain. This observed high prevalence rate corroborates the findings of previous authors from different parts of the country who reported a prevalence range between $66 \%$ and $85 \%$ among farmers [22,26,27]. This high prevalence of low back pain can be attributed to the considerable intensity of the physical activities required for farming combined with awkward postures in which those activities are being carried out.

The finding that both age and years of farming of the participants had significant influence on the prevalence of low back pain among the farmers shows that long exposure to manual farming predisposes to onset of low back pain. This agrees with findings of Fabunmi et al. [27] and Asuzu [22] who had earlier observed association between the number of years of farming and age and the prevalence of low back pain among Nigerian farmers. The increase in prevalence of low back pain as years of farming increase may be due to accumulation of repetitive strain of the muscles and ligaments of the back consequent to inconvenient posture assumed during farm activities. The high prevalence of low back pain among male farmers may be due to the fact that they are more involved in heavy manual physical activities than their 
female counterparts $[28,29]$. However, this finding disagrees with those of previous studies which concluded that LBP was more frequent among females [28,29]. This difference may be due to cultural and environmental differences.

This work was conducted in Nigeria while those of Haus et al. [28] and Thorbjornsson [29] were conducted in other countries. The farming jobs performed by Nigerian males are more physically demanding than those done by females, who are regarded as weaker gender and expected to support the males' major effort. This may explain the higher prevalence of low back pain observed among the males. Prolonged bending was observed to constitute a major risk factor of low back pain among farmers. This agrees with the causes of low back pain reported by other authors [9,30-32], who attributed low back pain to repeated strain on the back due to frequent bending at work.

Low back pain is a major public health concern, because it interferes with, or completely prevents farmers from, performing their farming duties and adversely affects their sexual activity. Steps should be taken as early as possible to prevent LBP development. The farmers' population should be made aware of the various alternative postures that are possible during farming activities. Government should also assist the farmers in reducing their physical effort through mechanization of the farming work. Loans should also be made available to local farmers to enable them to hire hands to assist them in their farming work. Low back pain is a major occupational health hazard among farmers. This will go a long way in preventing LBP among farmers.

\section{CONCLUSION}

There is a high prevalence of low back pain among farmers in South-West Nigeria and this is more predominant in male compared to female respondents. Age, sex and years of involvement in farming have a significant influence on the prevalence of low back pain.

\section{RECOMMENDATIONS}

1. The farmers should be provided with reliable knowledge on back care and low back pain prevention in order to minimize LBP frequency.

2. Ergonomics should be implemented in the design of farm tools to prevent excessive bending that has been identified as a major cause of LBP among farmers.

3. Government should encourage farmers to switch to mechanized farming by acquiring more advanced farm equipments that would make their work easier and faster without traumatizing their back.

\section{REFERENCES}

1. Walsh NE, Schwatz RK. The influence of prophylactic orthosis on the workplace. Am J Phys Ther Rehabil. 1990;65: 245-50, http://dx.doi.org/10.1097/00002060-199010000-00004.

2. Waddel G, Burton AK. Occupational health guidelines for management of low back pain of work. Occup Med. 2001;51:12435, http://dx.doi.org/10.1093/occmed/51.2.124.

3. Anderson G. Epidemiological features of chronic low back pain. Lancet. 1999;354:581-5, http://dx.doi.org/10.1016/S01406736(99)01312-4.

4. Wallner-Scholtfeldt P, Steward A. The predisposing factors for low back pain in workers. S Afr J Physiother. 2000;56(3):33-8.

5. Omokhodion FO. Low back pain in a rural community in South-West Nigeria. West Afr J Med. 2002;21(2):87-90.

6. Govender S. Low back pain in the nursing profession: A pilot study. S Afr Orthop J. 2004;7-13.

7. Jordaan R, Kruger M, Stewart A, Becker P. The association between low back pain, gender and age in adolescents. S Afr J Physiother. 2005;61(3):15-20.

8. Bejia I, Abid N, Salem K, Letaief M, Younes M, Touzi M, et al. Low back pain in a cohort of 622 Tunisian school children and adolescents. An epidemiological study. Eur Spine. 2005;14:331-6, http://dx.doi.org/10.1007/s00586-0040785-2. 
9. Owoeye IO. The science of human back and causes of back pain. J Niger Med Rehabil Ther. 1998;3(6):1-7.

10. Mckenzie R. The lumbar spine: Mechanical diagnosis and therapy. Waiknae: Spinal Publications; 1990.

11. Mckenzie R. Treat your own back. 3rd ed. New Zealand: Spinal Publications; 1985.

12. Sinaki M, Mokri B. Low back pain and disorders of lumbar spine. In: Braddom R, editor. Physical medicine and rehabilitation. Philadephia: WB Saunders; 2000. p. 853-93.

13. Low J, Reed A. Basic biomechanics explained. Oxford: Butterworth Heinemann; 1996.

14. Woolf A, Pfleger B. Burden of major musculoskeletal conditions. Bull World Health Organ. 2003;81(9):646-56.

15. Akinbo SRA. Physiotherapy management of low back pain: Manipulative therapy and thermal therapy techniques. J Niger Med Rehabil Ther. 1998;3:32-5.

16. Jameel IM, Robinson JS. Residual post-surgical back pain. J Med Assoc Ga. 1996;85:101-7.

17. Maniadakis N, Gray A. The economic burden of back pain in United Kingdom. Pain. 2000;84:95-103, http://dx.doi. org/10.1016/S0304-3959(99)00187-6.

18. Louw QA, Morris LD, Grimmer-Sommers K. The prevalence of low back pain in Africa: A systematic review. BMC Musculoskelet Disord. 2007;8:105, http://dx.doi. org/10.1186/1471-2474-8-105.

19. Malluf K, Sahrmanns, Van D. Use of a classification system to guide non-surgical management of patient with chronic low back pain. Phys Ther. 2000;80(11):1097-109.

20. Van Tulder M. An updated review refresher course syllabus. Seattle: IASP Press; 2002.

21. Omokhodion FO, Sanya AO. Risk factors for low back pain among office workers in Ibadan, South-West Nigeria. Occup Med. 2003;53:287-9, http://dx.doi.org/10.1093/occmed/ kqg063.
22. Asuzu MC. Community survey of backache in Igbo-Ora, Oyo State, Nigeria. Niger Med J. 1995;28(1):11-4.

23. Hilman M, Wright A, Rajaratman G. Prevalence of low back pain in the community: Implications for service provision in Bradford UK. J Epidemiol Community Health. 1996;50: 347-52, http://dx.doi.org/10.1136/jech.50.3.347.

24. Odebiyi DO, Ogwezi DC, Adegoke BOA. The prevalence of low back pain in commercial motor drivers and private automobile drivers. Niger J Med Rehabil. 2007;12(20):21-4.

25. Akinbo SR, Odebiyi DO, Osasan AA. Characteristics of back pain among commercial drivers and motorcyclists in Lagos. West Afr J Med. 2008;27(2):87-91.

26. Omokhodion FO. Low back pain in an urban community in South-West Nigeria. Trop Doct. 2004;34(1):17-20.

27. Fabunmi AA, Aba SO, Odunaiya NA. Prevalence of low back pain among peasant farmers in a rural community in South-West Nigeria. Afr J Med Med Sci. 2005;34:259-62.

28. Haus TS, Schouten JS, Lean ME, Seidell JC. The prevalence of low back pain and association with body fatness, fat distribution and height. Int J Obes Relat Metab Disord. 1997;21(7):646-54.

29. Thorbjornsson CO, Alfredsson L, Fredriksson K, Köster M, Michélsen H, Vingård E, et al. Psychological and physical risk factors associated with low back pain: A 24 year follow up among women and men in a broad range of occupations. Occup Environ Med. 1998;55:84-90, http://dx.doi. org/10.1136/oem.55.2.84.

30. Anannontsak A, Puapan P. Effect of working postures on low back pain. J Hum Ergol. 1996;25(1):65-72.

31. Xu Y, Bach E, Orhede E. Work environment and low back pain: The influence of occupational activities. Occup Environ Med. 1997;54:741-5, http://dx.doi.org/10.1136/oem.54.10.741.

32. Cassidy JD, Carol LJ, Cote P. The Saskatchewan Health and Back Pain Survey. Spine. 1998;23(17):1860-7, http://dx.doi. org/10.1097/00007632-199809010-00012.

This work is available in Open Access model and licensed under a Creative Commons Attribution-NonCommercial 3.0 Poland License - http://creativecommons.org/ licenses/by-nc/3.0/pl/deed.en. 